\title{
Effect of Different Heat-treated Nickel- Titanium Files on Vertical Root Fracture Resistance
}

\author{
Farklı Isıl İşlem ile Üretilmiş Nikel-Titanyum Eğelerin Vertikal Kök \\ Kırık Direncine Etkisi \\ (D) Fatma Furuncuoğlü ${ }^{1}$, (1) Elif Kalyoncuoğlu² \\ ${ }^{1}$ Sakarya University Faculty of Dentistry, Department of Endodontics, Sakarya, Turkey \\ ${ }^{2}$ Ondokuz Mayıs University Faculty of Dentistry, Department of Endodontics, Samsun, Turkey
}

Keywords

CM-Wire, instron, M-Wire, thermal treatment, vertical root fracture

\author{
Anahtar Kelimeler \\ CM-Wire, instron, M-Wire, ısıl işlem, dikey \\ kök kırığı
}

Received/Geliş Tarihi : 30.07 .2020

Accepted/Kabul Tarihi : 23.03.2021

doi:10.4274/meandros.galenos.2021.77699

Address for Correspondence/Yazışma Adresi: Fatma Furuncuoğlu MD,

Sakarya University Faculty of Dentistry, Department of Endodontics, Sakarya, Turkey

Phone : +902642954203

E-mail : fatma@sakarya.edu.tr

ORCID ID: orcid.org/0000-0001-5986-1508

(C) Meandros Medical and Dental Journal, Published by Galenos Publishing House.

This is article distributed under the terms of the Creative Commons Attribution NonCommercial 4.0

International Licence (CC BY-NC 4.0).

\begin{abstract}
Objective: This study aimed to evaluate the fracture resistance of teeth instrumented with rotary files manufactured from different heat-treated nickel-titanium (NiTi) wires.

Materials and Methods: One hundred extracted single-canal mandibular premolar teeth were sectioned, leaving a standard root length of $13 \mathrm{~mm}$. Samples were matched with respect to the buccolingual-mesiodistal diameters. They were randomly divided into four experimental groups and one control group $(n=20)$ : Control group, no preparation or obturation; ProTaper Universal (PTU) group, prepared with the PTU system as a universal NiTi; Twisted File (TF) group, prepared with the TF system as an R-phase treatment; ProTaper Next (PTN) group, prepared with the PTN system as an M-Wire thermal treatment; and HyFlex Controlled Memory (HCM) group, prepared with the HCM system as a CM-Wire thermal treatment. After preparations, samples were obturated with gutta-percha and sealer. Samples were subjected to a vertical loading force of $1 \mathrm{~mm} / \mathrm{min}$ until fracture occurred. Data were subjected to statistical analysis using One-way ANOVA ( $p=0.05)$ and Tukey tests.

Results: Although the control group had the highest root fracture resistance value, the differences between the control group and HCM group was not significant ( $p>0.05)$. Except for the control group, the differences among the study groups were not significant ( $p>0.05)$.

Conclusion: Different heat treatments of instruments have no effects on vertical root fracture resistance.
\end{abstract}

Öz

Amaç: Bu çalışmanın amacı, farklı ısıl işlem görmüş nikel-titanyum (NiTi) tellerinden üretilen döner eğeler ile prepare edilen dişlerin kırılma direncini değerlendirmektir. Gereç ve Yöntemler: Yüz adet tek kanallı mandibular premolar diş standart kök uzunluğu $13 \mathrm{~mm}$ olacak şekilde separe edilmiştir. Örnekler mesiodistal ve bukkolingual boyutları benzer olacak şekilde seçildi $(p>0,05)$. Örnekler 4 çalışma grubu ve 1 kontrol grubu olacak şekilde rastgele dağıtıldı $(n=20)$ : Kontrol grubu; preparasyon ve obturasyon yapılmadı. Grup ProTaper Universal (PTU); PTU sistemi, grup Twisted File (TF); TF sistemi, grup ProTaper Next (PTN); PTN sistemi, Grup HyFlex 
Controlled Memory (HCM); HCM sistemi kullanılarak örneklerin preparasyonu tamamlandı. Preparasyonların ardından örnekler güta perka ve kanal patı ile dolduruldu. Örneklere kırık oluşana kadar $1 \mathrm{~mm} / \mathrm{dk}$ hızında vertikal yükleme yapıldı. Elde edilen verilerin istatistiksel analizi Tek yönlü varyans analizi ve Tukey testi ile gerçekleştirildi $(p=0,05)$.

Bulgular: Kontrol grubu en yüksek kırık direnci değerini gösterirken grup HCM ile aralarında istatistiksel olarak anlamlı bir fark bulunamadı ( $p>0,05)$. Çalışma gruplarının aralarında da anlamlı bir fark bulunamadı.

Sonuç: Eğelere uygulanan ısıl işlemlerdeki farklılığın vertikal kök kırık direnci üzerine etkisi bulunmamaktadır.

\section{Introduction}

One of the most severe complications related with the root canal treatment is the vertical root fractures and they were reported to frequently cause tooth extraction (1). The main reasons for the higher fracture susceptibility of the teeth, which have endodontic treatment history, are the cumulative loss of tooth structure from the caries, as well as the trauma and the restorative and endodontic procedures (2). It is known that many predisposing factors increase the predilection of the root-filled teeth to vertical root fractures (VRFs). Some of these predisposing factors are the removal of an excessive amount of dentine during the operative procedures or root canal preparation (3), post-space preparation (4), and the dentinal defects emerging in these procedures.

It was concluded that, the root canal preparation performed by using nickel-titanium (NiTi) instruments induced more dentinal damage when compared to the level of damage caused by the hand files (5). In the procedures performed by using NiTi instruments, a force is inevitably applied on or around the apex. As a result of these forces, the strain on the dentinal walls increases and, thus, the dentinal micro-crack occurs (6). In previous researches $(6,7)$ it was reported that different levels of damages on the root canal wall were observed when different root canal shaping instruments were utilized.

Many different NiTi rotary file systems have been introduced to the market by different companies. These instruments have different characteristics in terms of the design of cutting blades, as well as the body taper and tip configuration. Moreover, different thermal treatments are applied in order to improve the characteristics of NiTi instruments such as the cyclic fatigue resistance, shaping efficiency, and transportation amount. In the production of Twisted File (TF; SybronEndo, Orange, CA), which has been developed in year 2008, three methods are combined in the production process. These methods are heat treatment (R-phase), twisting the metal wire, and special surface conditioning. ProTaper Next (PTN; Dentsply Sirona, Ballaigues, Switzerland) systems are produced by making use of M-Wire technology and these instruments have an off-centered rectangular design, as well as the progressive and regressive percentage tapers on a single file. It was reported that the snake-like motion minimized the contact between the instrument and dentin and, thus, reduced the screw effect, dangerous taper lock, and torque on the files (8). Introduced to the market in year 2011, the HyFlex Controlled Memory (HCM; ColteneWhaledent, Allst€atten, Switzerland) is a NiTi rotary system is made of CM alloy. The CM alloy used in the production of NiTi files are of no shape memory, which is seen in traditional NiTi files, and the thermomechanical method employed in manufacturing the HCM instruments aims to improve the flexibility of traditional NiTi files (9).

In the recent years, different researchers investigate the effects of different rotary file systems $(10,11)$, preparations performed with different tapers $(12,13)$, and different kinematics (14) on the vertical root fracture of the teeth, which have root canal treatment history. In the present study, it is aimed to examine the effects of various instruments, which have been exposed to heat treatments, on the fracture resistance of the roots, which have endodontic treatment history. The null hypothesis of the present study is that different heat treatments would have no effect on the vertical root fracture resistance.

\section{Materials and Methods}

For the study Ethics Committee approval was received by Ondokuz Mayıs University (decision no: KAEK 2014/663, date: 24.04.2014). A hundred mandibular premolar teeth, which were extracted for orthodontic reasons, colected and stored in saline solution for the study. The teeth were examined radyografically. Single and straight roots with matured 
apex were determinated and included the study. Under water cooling, coronal parts of the teeth were removed from the roots with diamond coated bur. The root lengths were standardized to $13 \mathrm{~mm}$. Roots examinated with stereomicroscope at $\times 10$ magnification and undamaged roots were included the study. For standardization, dimensions of roots at the coronal ends which range from 4-6 $\mathrm{mm}$ in buccolingual (BL) aspects, 2-4 $\mathrm{mm}$ in mesiodistal (MD) aspect were choosed (15). All samples were randomly divided into five groups $(n=20)$. Analysis of variance test performed to evaluate size differences of the roots and no significant differences were found $[B L$ $(p=0.687), M D(p=0.999)]$ between groups. All root canals were checked for any calsifications or blockage with a size $15 \mathrm{~K}$-file. Then root canal preparations were performed with different NiTi systems.

\section{Root Canal Preparations}

The study groups are given in Table 1 .

In control group, no instrumentation or obturation was performed.

Group ProTaper Universal (PTU): The root canals were englarged by single experienced operator with the PTU rotary system driven by a torque-controlled endodontic motor VDW Gold (VDW, Münih, Germany) according to the manufacturer's instructions. The SX file was used with a brushing motion at coronal part of the root; then S1, S2 files were placed in the root canal and withdraw the file once the working length $(W L)$ is reached. The root canals were prepared with
F1 (20/.07), F2 (25/.08), F3 (30/.06), and F4 (40/.06) files respectively with a gentle in-and-out motion.

Group TF: The root canals were prepared with the TF system according to the manufacturer's instructions, using VDW Gold. The TF files (20/.04), (25/.06), (25/.08), (30/.06), (35/.06), and (40/.04) were used to the WL with a gentle in-and-out motion at $500 \mathrm{rpm}$ and $4 \mathrm{Ncm}$ torque.

Group PTN: The root canals were prepared with the PTN system using at $300 \mathrm{rpm}$ and $2 \mathrm{Ncm}$ torque using a VDW Gold. The SX file was used at coronal part of the root with a brushing motion. The root canal preparation was performed up to $\mathrm{X} 4$ at the $\mathrm{WL}$ with a gentle in-and-out motion. The files were used respectly; X1 (17/.04), X2 (25/.06), X3 (30/.06), and X4 files (40/.06).

Group HCM: The HCM system were used in a gentle in-and-out motion with a rotational speed of $500 \mathrm{rpm}$ and $250 \mathrm{~g} / \mathrm{cm}$ torque. The HCM were used in the sequence of $25 / .08$ (two thirds of the $W L$ ), 25/.06, $30 / .06$, and 40/.04 (the full WL).

During preparation, each sample was irrigated with $5 \mathrm{~mL}$ of $2.5 \%$ sodium hypochlorite with a side vented needle. After instrumentation, the root canals were irrigated with $2 \mathrm{~mL}$ of $17 \%$ ethylenediaminetetraacetic acid for $3 \mathrm{~min}$, and the final irrigation was performed by $5 \mathrm{~mL} 2.5 \%$ sodium hypochlorite. The root canals dried with their respective paper points. The root canal obturation was performed using the single cone technique with competible gutta percha systems and

Table 1. Thermal treatment methods and NiTi files included in the study

\begin{tabular}{|l|l|l|}
\hline Groups & Thermal treatment methods & NiTi system and manufacturer \\
\hline Group PT & Universal NiTi & ProTaper Universal; Dentsply, Sirona \\
\hline Group TF & R-phase & Twisted File; SybronEndo \\
\hline Group PTN & M-Wire & Protaper Next; Dentsply, Sirona \\
\hline Group HCM & Controlled Memory & HyFlex CM; Coltene-Whaledent \\
\hline NiTi: Nickel-titanium, PT: ProTaper, TF: Twisted File, PTN: ProTaper Next, HCM: HyFlex Controlled Memory, CM: Controlled Memory
\end{tabular}

Table 2. Fracture loads of the roots as mean, maximum, and minimum Newton

\begin{tabular}{|l|l|l|l|l|l|} 
& \multicolumn{2}{|c|}{ NiTi System } \\
\cline { 2 - 6 } & Control & ProTaper Universal & Twisted File & ProTaper Next & HyFlex CM \\
\hline Mean & $143.94 \pm 32.7^{\mathrm{b}}$ & $105.31 \pm 20.07^{\mathrm{a}}$ & $111.21 \pm 26.21^{\mathrm{a}}$ & $102.38 \pm 20.20^{\mathrm{a}}$ & $121.57 \pm 43.29^{\mathrm{ab}}$ \\
\hline Maximum & 206.96 & 138.68 & 157.99 & 145.68 & 237.99 \\
\hline Minimum & 83.02 & 72.59 & 69.16 & 69.63 & 60.73 \\
\hline *Different superscript letters indicate a significant difference $(\mathrm{p}<0.05)$. CM: Controlled Memory, NiTi: Nickel-titanium \\
\hline
\end{tabular}


resin based sealer; AH Plus (Dentsply, De Trey, Kontanz, Germany). The coronal excess of the specimen was sealed with temporary filling material (3M ESPE, St. Paul, MN, USA), and the roots were kept in $100 \%$ humidity for 2 weeks.

\section{Fracture Resistance Test}

Acrylic resin blocks $(25 \mathrm{~mm}$ high and $10 \mathrm{~mm}$ in diameter) were prepared using cylindrical plastic molds with self-cured acrylic resin (Imicryl, Konya, Turkey). The apical root ends were embedded vertically in $4 \mathrm{~mm}$ of the acrylic resin, exposing $9 \mathrm{~mm}$ of the coronal portion of each root (Figure 1 ) (10). For preventing dehydration, the roots were kept wet with a wet towel until strength test. Acrylic blocks including specimens were placed in a universal testing machine (Autograph AG-X; Shimadzu Corporation, Kyoto, Japan). A compressive vertical loading at a speed of 1 $\mathrm{mm} / \mathrm{min}$ was applied. The force at which the fracture occurred was recorded in Newtons.

\section{Statistical Analysis}

SPSS (SPSS Version 20, SPSS Inc, Chicago, IL) software was used for statistical analysis. Descriptive statistics, Shapiro-Wilk, One-way ANOVA and Tukey analysis were performed. The results for $p<0.05$ was considered statistically significant.

\section{Results}

Table 2 summarizes the means and standard deviations and minimum and maximum fracture loads of the experimental groups. Group HCM was the most resistant to fracture $(121.57 \pm 43.29 \mathrm{~N})$, and group PTN was the least resistant (102.38 $\pm 20.20 \mathrm{~N})$. The mean of the fracture values is shown graphically in Figure 2.

\section{Discussion}

The diagnosis and treatment of the vertical root fracture are very difficult and it may require the extraction of the tooth $(2,16,17)$. In literature, there are various studies carried out on the instrument diameters, different kinematics, and root canal filling methods influencing the vertical root fracture. However, there is no study examining the heat treatments applied to the instruments. For this reason, the present study aims to compare the VRF resistances of the teeth by making use of various $\mathrm{NiTi}$ files, which have been exposed to different thermal procedures. In the present study, there were no significant difference between PT, TF, PTN and HCM $(p \geq 0.05)$. Thus, the null hypothesis was accepted.

In the present study, it was aimed to maximally standardize all of the controllable variables. The $\mathrm{BL}$ and MD widths of the samples were examined and included those that were not statistically different between them $(p>0.05)$. As stated in previous studies $(10,11,15)$, the differences between the dimensions of the roots influence the residual dentin thickness that will be seen after the instrumentation by using different tapers. Thus, the apical diameters of all the root canals were enlarged to ISO \#40 $(10-13,18)$. Root canal preparations were completed by selecting different heat-treated files with this apical diameter (PTU 40/.06, TF 40/.04, PTN 40/.06, HCM 40/.04). This situation created a difference in the taper of the preparations. Actually, one of the factors affecting the predisposition to vertical root fracture is the diameter of the prepared canal. As reported in previous studies

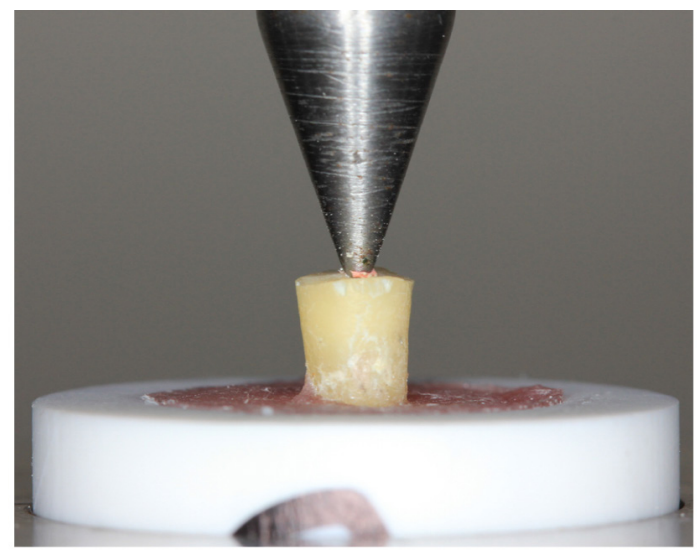

Figure 1. A specimen prepared for Instron machine to test the fracture strength

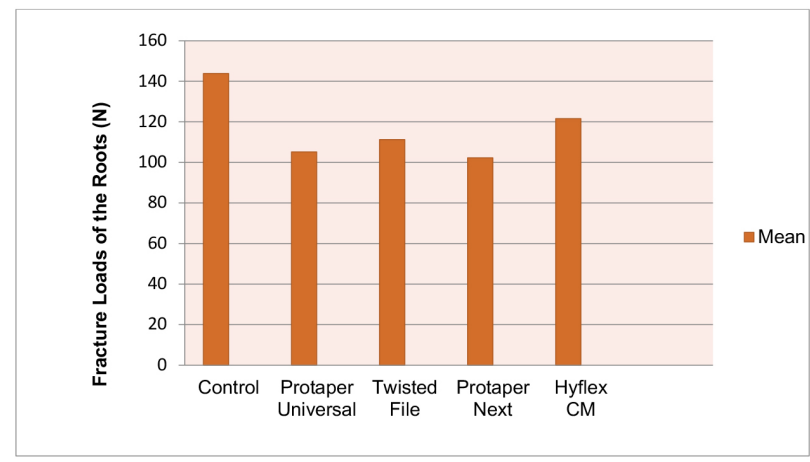

Figure 2. Fracture loads of the roots as mean $\mathrm{CM}$ : Controlled Memory, N: Newton 
$(3,4,19,20)$, it is known that the fracture resistance of the teeth, which have endodontic treatment history, is directly proportionate to the amount of remaining sound tooth structure. Wilcox et al. (19) reported that the preparation performed by using hand files or the lateral condensation does not damage the tooth but the tooth would be more inclined to fracture when an excessive amount of dentin is removed. Krikeli et al. (13) examined the preparations performed using different tapers in terms of the vertical fracture resistance, and authors reported that the roots enlarged using .06 taper had less resistance to the fracture than in the control group, whereas there was no significant difference between the control group and the other groups, in which the enlargement was performed using smaller tapers, in terms of fracture resistance.

On the contrary in the present study; although both HCM and TF have a .04 taper, there is no difference between the HCM group and control group, while there is a difference between the TF group and the control group. This difference may be due to the difference in material between files. Abou El Nasr et al. (14) in the study comparing the effect of the material used and kinematics on fracture resistance, reported that the material difference had an effect on fracture resistance. In addition, $\mathrm{M}$-wire and $\mathrm{Cm}$-Wire wires are more flexible (21) and it has been reported in studies that HCM has a better centering ability compared to TF $(22,23)$. Thus, the original form of the root canal is protected and the increase in the risk of vertical fracture might be eliminated by preventing the formation of thin dentin zones $(20,24)$. In the present study, the statistically insignificant difference between HCM system and control group $(p \geq 0.05)$ may arise from the .04 taper and $\mathrm{CM}$ heat treatment.

In many studies, it was emphasized that the NiTi instruments may lead to cracks in the root dentine $(6,7,25)$ and this may cause the vertical root fractures. It is believed that these micro-cracks, which are seen on the dentinal walls after the preparation, create stress accumulation zones on the dentinal walls and cause VRF formation when an external force is applied (26). In previous studies, it was emphasized that the taper of files might be the most important factor playing role in the formation of dentinal cracks $(27,28)$. In addition to the studies; reporting that different file systems caused micro-cracks but HCM system did not
$(7,29)$, also there is a study reporting that HCM caused less micro-crack formation than PTU and PTN systems did (30). In the present study, it was found that there is no statistically significant difference between HCM system and control group ( $p \geq 0.05)$. When compared to the other groups in this study, HCM system created less or no micro-crack. In the recent studies, it was reported that there were micro-cracks before the root canal preparation $(7,31)$ but the number of microcracks increased after the preparation (32). De-Deus et al. (33) reported that the micro-cracks do not exist in the teeth in the intraoral environment but they form under the storage conditions, whereas Shemesh et al. (34) reported that the dehydration played an effective role in the formation of dentinal micro-cracks. Further studies examining the formation of micro-crack and its relationship with the vertical fracture are need.

\section{Conclusion}

Within the limitations of the present study, preparations of roots with PTU, TF, and PTN reduced the vertical fracture resistance of roots when compared with the control group. In addition fracture resistance of preparation of roots with $\mathrm{HCM}$ did not showed differences from control group, significantly. Further studies are warranted to evaluate the effect of heat treatment of NiTi files on the mechanical properties of endodontically treated teeth.

\section{Ethics}

Ethics Committee Approval: For the study Ethics Committee approval was received by Ondokuz Mayıs University (decision no: KAEK 2014/663, date: 24.04.2014).

Informed Consent: Written informed consent was obtained from all participants.

Peer-review: Externally peer-reviewed.

\section{Authorship Contributions}

Concept: F.F., E.K., Design: F.F., E.K., Supervision: E.K., Fundings: F.F., E.K., Materials: F.F., Data Collection or Processing: F.F., E.K., Analysis or Interpretation: F.F., E.K., Literature Search: F.F., Writing: F.F., Critical Review: E.K.

Conflict of Interest: No conflict of interest was declared by the authors.

Financial Disclosure: The Ondokuz Mayıs University Scientific Research Projects Coordination Unit support this study financially (PYO.DIS.1904.14.008). 


\section{References}

1. Tang $\mathrm{W}, \mathrm{Wu} \mathrm{Y}$, Smales RJ. Identifying and reducing risks for potential fractures in endodontically treated teeth. J Endod 2010; 36: 609-17.

2. Tsesis I, Tamse A, Lustig J, Kaffe I. [Vertical root fractures in endodontically treated teeth part I: clinical and radiographic diagnosis]. Refuat Hapeh Vehashinayim (1993) 2006; 23: 13-7.

3. Cohen S, Berman LH, Blanco L, Bakland L, Kim JS. A demographic analysis of vertical root fractures. J Endod 2006; 32: 1160-3.

4. Kishen A. Mechanisms and risk factors for fracture predilection in endodontically treated teeth. Endod Topics 2006; 13: 57-83.

5. Bier CA, Shemesh H, Tanomaru-Filho M, Wesselink PR, Wu MK. The ability of different nickel-titanium rotary instruments to induce dentinal damage during canal preparation. J Endod 2009; 35: 236-8.

6. Adorno CG, Yoshioka T, Suda H. Crack initiation on the apical root surface caused by three different nickel-titanium rotary files at different working lengths. J Endod 2011; 37: 522-5.

7. Bayram HM, Bayram E, Ocak M, Uzuner MB, Geneci F, Celik $\mathrm{HH}$. Micro-computed Tomographic Evaluation of Dentinal Microcrack Formation after Using New Heat-treated Nickeltitanium Systems. J Endod 2017; 43: 1736-9.

8. van der Vyver PJ, Paleker F, Vorster M, de Wet FA. Root Canal Shaping Using Nickel Titanium, M-Wire, and Gold Wire: A Microcomputed Tomographic Comparative Study of One Shape, ProTaper Next, and WaveOne Gold Instruments in Maxillary First Molars. J Endod 2019; 45: 62-7.

9. Uslu G, Özyürek T, Yılmaz K. Comparison of Alterations in the Surface Topographies of HyFlex CM and HyFlex EDM Nickeltitanium Files after Root Canal Preparation: A Three-dimensional Optical Profilometry Study. J Endod 2018; 44: 115-9.

10. Capar ID, Altunsoy M, Arslan H, Ertas H, Aydinbelge HA. Fracture strength of roots instrumented with self-adjusting file and the ProTaper rotary systems. J Endod 2014; 40: 551-4.

11. Çiçek E, Aslan MA, Akkoçan O. Comparison of the Resistance of Teeth Instrumented with Different Nickel-Titanium Systems to Vertical Root Fracture: An In Vitro Study. J Endod 2015; 41: 1682-5.

12. Zandbiglari T, Davids H, Schäfer E. Influence of instrument taper on the resistance to fracture of endodontically treated roots. Oral Surg Oral Med Oral Pathol Oral Radiol Endod 2006; 101: 126-31.

13. Krikeli E, Mikrogeorgis G, Lyroudia K. In Vitro Comparative Study of the Influence of Instrument Taper on the Fracture Resistance of Endodontically Treated Teeth: An Integrative Approach-based Analysis. J Endod 2018; 44: 1407-11.

14. Abou El Nasr HM, Abd El Kader KG. Dentinal damage and fracture resistance of oval roots prepared with single-file systems using different kinematics. J Endod 2014; 40: 849-51.

15. Ersev H, Yilmaz B, Pehlivanoğlu E, Ozcan-Çalişkan E, Erişen FR. Resistance to vertical root fracture of endodontically treated teeth with MetaSEAL. J Endod 2012; 38: 653-6.

16. Tamse A. Vertical root fractures of endodontically treated teeth. In: Ingle JI, Bakland LK, Baumgartner JC, eds. Ingle's endodontics. 6th ed. Hamilton, Ontario, Canada: BC Decker Inc, 2008: 676-89.

17. Tsesis I, Rosen E, Tamse A, Taschieri S, Kfir A. Diagnosis of vertical root fractures in endodontically treated teeth based on clinical and radiographic indices: a systematic review. J Endod 2010; 36: 1455-8.

18. Ghoneim AG, Lutfy RA, Sabet NE, Fayyad DM. Resistance to fracture of roots obturated with novel canal-filling systems. J Endod 2011; 37: 1590-2.

19. Wilcox LR, Roskelley C, Sutton T. The relationship of root canal enlargement to finger-spreader induced vertical root fracture. J Endod 1997; 23: 533-4.

20. Sornkul E, Stannard JG. Strength of roots before and after endodontic treatment and restoration. J Endod 1992; 18: 440-3.

21. Pereira ES, Peixoto IF, Viana AC, Oliveira II, Gonzalez BM, Buono VT, et al. Physical and mechanical properties of a thermomechanically treated NiTi wire used in the manufacture of rotary endodontic instruments. Int Endod J 2012; 45: 469-74.

22. Pinheiro SR, Alcalde MP, Vivacqua-Gomes $N$, Bramante CM, Vivan RR, Duarte MAH, et al. Evaluation of apical transportation and centring ability of five thermally treated NiTi rotary systems. Int Endod J 2018; 51: 705-13.

23. Kishore A, Gurtu A, Bansal R, Singhal A, Mohan S, Mehrotra A. Comparison of canal transportation and centering ability of Twisted Files, HyFlex controlled memory, and Wave One using computed tomography scan: An in vitro study. J Conserv Dent 2017; 20: 161-5.

24. Versluis A, Messer HH, Pintado MR. Changes in compaction stress distributions in roots resulting from canal preparation. Int Endod J 2006; 39: 931-9.

25. Yoldas O, Yilmaz S, Atakan G, Kuden C, Kasan Z. Dentinal microcrack formation during root canal preparations by different NiTi rotary instruments and the self-adjusting file. J Endod 2012; 38: 232-5.

26. Adorno CG, Yoshioka T, Jindan P, Kobayashi C, Suda H. The effect of endodontic procedures on apical crack initiation and propagation ex vivo. Int Endod J 2013; 46: 763-8.

27. Alfoqom Alazemi M, Bryant ST, Dummer PM. Deformation of HyFlex CM instruments and their shape recovery following heat sterilization. Int Endod J 2015; 48: 593-601.

28. Ashwinkumar V, Krithikadatta J, Surendran S, Velmurugan N. Effect of reciprocating file motion on microcrack formation in root canals: an SEM study. Int Endod J 2014; 47: 622-7.

29. Kfir A, Elkes D, Pawar A, Weissman A, Tsesis I. Incidence of microcracks in maxillary first premolars after instrumentation with three different mechanized file systems: a comparative ex vivo study. Clin Oral Investig 2017; 21: 405-11.

30. Ashraf F, Shankarappa P, Misra A, Sawhney A, Sridevi N, Singh A. A Stereomicroscopic Evaluation of Dentinal Cracks at Different Instrumentation Lengths by Using Different Rotary Files (ProTaper Universal, ProTaper Next, and HyFlex CM): An Ex Vivo Study. Scientifica (Cairo) 2016; 2016: 8379865.

31. De-Deus G, Belladonna FG, Marins JR, Silva EJ, Neves AA, Souza $E M$, et al. On the Causality Between Dentinal Defects and Root Canal Preparation: A Micro-CT Assessment. Braz Dent J 2016; 27 : 664-9. 
32. Ceyhanli KT, Erdilek N, Tatar I, Celik D. Comparison of ProTaper, $\mathrm{RaCe}$ and Safesider instruments in the induction of dentinal microcracks: a micro-CT study. Int Endod J 2016; 49: 684-9.

33. De-Deus G, Cavalcante DM, Belladonna FG, Carvalhal J, Souza EM, Lopes RT, et al. Root dentinal microcracks: a post-extraction experimental phenomenon? Int Endod J 2019; 52: 857-65.
34. Shemesh H, Lindtner T, Portoles CA, Zaslansky P. Dehydration Induces Cracking in Root Dentin Irrespective of Instrumentation: A Two-dimensional and Three-dimensional Study. J Endod 2018; 44: 120-5. 